
wzakresiefilologii, młodszy pracownik naukowy w Instytucie Literatury

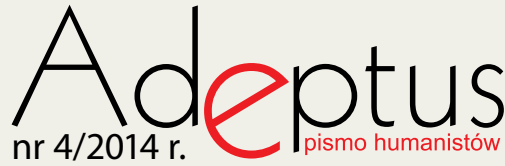
Rosyjskiej (Dom Puszkina) Rosyjskiej Akademii Nauk. Ukończyła studia magisterskie na Wydziale Filologicznym Petersburskiego Uniwersytetu Państwowego na kierunku ,język i literatura czeska, język angielski”. Pracę doktorską w ramach specjalizacji „literatura rosyjska" obroniła w Instytucie Literatury Rosyjskiej Rosyjskiej Akademii Nauk (ИРЛИ РАН). Odbyła staże naukowe na Uniwersytecie Karola (Praga), na Uniwersytecie Ostrawskim, na Uniwersytecie Palackiego w Ołomuńcu, na Uniwersytecie Jagiellońskim w Krakowie. Zainteresowania naukowe: filologia słowiańska, historia literatury rosyjskiej, słowiańskie kontakty literackie

\title{
Подкарпатская Русь в составе Чехословакии: история, культура, национальная идентичность
}

$\mathrm{H}$ ачало политической истории Подкарпатской Руси в качестве автономии, входящей в состав Первой Чехословацкой Республики, было положено Сен-Жерменским мирным договором 10 сентября 1919 г. Третья секция этого договора была посвящена установлению границ нового славянского государства. Это был первый официальный документ, устанавливающий автономию русинских земель в составе Чехословакии. Однако название автономной области долгое время оставалось предметом дискуссий. В Меморандуме о Подкарпатской Руси, который является одним из первых официальных чехословацких документов, посвященных экономическим, политическим и культурным проблемам региона, было обозначено: «Название региона и населения все еще не установлено» („Memorandum”, 1997, с. 7). В 1919 г., когда появилась первая редакции «Generalního Stautu pro organisaci a administraci Přikarpatské Rusi», бытовало несколько названий для русинских территорий: 'Пржикарпатская Русь', ‘Подкарпатская Русь' и 'Русинско' (образовано по примеру чешских и словацких названий стран. Ср., 'Словенско, 'Ческословенско'). 
Причем в ряде документов отмечалось, что закрепление названия Русинско в качестве официального наименования автономной области является наиболее рациональным решением вопроса. Все три варианта названия использовались на протяжении первых лет существования подкарпатской автономии. Известное нам сейчас название - Подкарпатская Русь - окончательно закрепилось только в 1920 г. в тексте Конституции Чехословакии, что может быть связано со сложным процессом присоединения этих земель к Чехословацкой республике и существовавшей вплоть до 1920 г. неоднозначности в отношении государственной границы и даже угрозы будущему демократическому строю на подкарпатских территориях (так, в 1918-1919 гг. русины провозгласили независимую советскую Руську Краину). Чешский писатель Иван Ольбрахт (1882-1952), автор вышедшей в 1935 г. серии репортажей о Подкарпатской Руси, назвал эту область «землей без имени», что соответствовало реальности: для многих представителей чехословацкой элиты эта земля так и не получила имени, оставалась неизвестной, заповедной территорией.

История Подкарпатской Руси, на наш взгляд, может быть рассмотрена как история воображаемого сообщества, национальный миф которого на протяжении нескольких столетий конструировался извне. В XIX веке основы национального самоопределения этого сообщества были заложены в трудах славянских будителей (Šafařík, 1826), а также в работах карпаторусских политических и культурных деятелей (Духнович, 1981; Лучкай, 1999-2004). Новая же политическая история этого региона, возникшего на обломках Австро-Венгерской империи, творилась в кабинетах чехословацких министров, на страницах чехословацких литературных произведений. (Например, роман Ивана Ольбрахта «Разбойник Никола Шугай» (1933 г.) или Карела Чапека «Гордубал» (1933 г.)).

В двадцатые годы некоторые представители чешских и словацких ученых были командированы в Подкарпатскую Русь для изучения традиций, культуры и быта этого региона. Вероятно, результатом такой командировки являлись работы министра внутренних дел и журналиста Яромира Нечаса (1888-1945), в которых подробно анализировались все общественные и политические движения в регионе, перспективы развития внедренных Чехословакией образовательных программ и особенности языковой ситуации в подкарпатской области (Nečas, 1997). В 1920-30-е гг. возникло множество исследований подобного рода: географические описания подкарпатских территорий, исторические обзоры, путеводители для чехословацких туристов, этнографические заметки. 
Присоединение Подкарпатской Руси к Чехословакии поставило перед правительством Масарика ряд вопросов, которые требовали скорейшего разрешения. Во-первых, необходимо было осмыслить само понятие автономной области в составе республики и определить взаимодействие русинского сейма с чехословацким правительством. Это был очень противоречивый и сложный процесс, который болезненно сказывался на становлении русинского национального самосознания, поскольку полная автономия края так и не была осуществлена. Экономические проблемы региона также приходилось решать правительству за счет бюджета Чехословакии. Пражский Град был вынужден объяснять свое намерение оказывать всестороннюю финансовую поддержку Подкарпатской Руси в официальных речах, обращенных к чехословацкому населению, настроенному крайне скептически по отношению к расширению государственных границ за счет присоединения мало развитого с экономической и культурной точки зрения региона. В 1924 г. об этой волне интереса к Подкарпатской Руси высказался журналист и исследователь русинских политических течений Антонин Гартл (1885-1944), заметив, что «со всех сторон слышны призывы к научному изучению Подкарпатской Руси и разговоры о возможностях, которые она предоставляет для исследовательской деятельности, ведь это девственно чистая территория; научная мысль ее или вовсе не коснулась, или коснулась лишь поверхностно» (Hartl, 1924, с. 2).

Чехословацкие политики (в частности, Эдвард Бенеш (1884-1948)) ссылались на ответственность Чехословакии перед русинами, которые международным решением переходили под братскую опеку молодой славянской республики. Именно эту идею подчеркнул также историк Камил Крофта (1876-1945) в цикле лекций, прочитанных в двадцатые годы в Ужгороде и Мукачево. Он отметил, что Чехословакия должна «исполнить великую миссию, на нее возложенную, и старательно заботиться о повышении культурного и социального уровня в регионе» (Krofra, 1995, c. 33). Еще более патетично обращался к русинам и всему чехословацкому обществу премьер-министр, а позже министр иностранных дел, Эдвард Бенеш, который заявил, что «единственная надежда подкарпатского народа - это Чехословакия» (Beneš, 1996, с. 16). В отдельных работах Подкарпатская Русь называлась с долей иронии и снисхождения «чехословацким любимчиком и баловнем» (Kochanyj-Goralčuk, 1931, c. 5), звучали и невероятные предположения о великой миссии Чехословакии в деле спасения гибнущего русского народа, представленного русинами, обращающимися за помощью к братьям чехам 
и словакам (Hora, 1919, с. 28). Подобная агитация могла иметь успех в обществе, которое еще недавно также обращало свои взгляды к России в поисках помощи и защиты.

Необходимость многократно повторять мысль о великом долге Чехословакии перед Подкарпатской Русью и обосновывать стратегическую важность включения этого региона в состав республики была продиктована скептическим отношением чешской и словацкой общественности к расширению границ государства за счет бедного и мало развитого региона. Подкарпатские земли воспринимались обществом как чужие, случайно попавшие под чехословацкую опеку. Более того, существовало опасение, что вскоре весь подкарпатский регион нужно будет вернуть хозяину (Венгрии или даже России). Это повлекло за собой восприятие подкарпатской политики, проводимой правительством, как временной акции, ненужной чехословацкому обществу. Так, профессор Карел Кадлец (1865-1928), высказавшийся о проблемах региона одним из первых, прямо назвал Чехословацкую республику «временным держателем чужого имущества» (Krofra, 1995, с. 5). Его взгляды разделял профессор Виктор Дворский, который в работе, опубликованной в 1925 г. в книге «Восемь лекций о Подкарпатской Руси», определил русинскую политику Чехословакии следующим образом: «как можно лучше приготовить этот регион для будущего хозяина, который присоединит его к своему имуществу» (Krofra, 1995, с. 5).

Чехословакия столкнулась с целым рядом проблем: от необходимости оказывать финансовую помощь и поддержку региону, до конструирования мифа о долге республики по отношению к карпатским братьям и высшем призвании чехословацкого общества, которое возложено на него мировыми державами. Однако наиболее сложным и противоречивым оказался языковой вопрос, который на протяжении столетий являлся поводом для дискуссии между приверженцами украинофильских и русофильских взглядов на проблему кодификации русинского языка.

В Генеральном Стауте, отразившем основные принципы организации культурной, политической и экономической жизни региона, проблема языка была прописана так:

«Лучше всего языковой вопрос будет решен следующим способом: в школах языком обучения станет язык народный, он также будет официальным языком вообще. В старших классах средних школ, а по необходимости и в остальных, может быть введен великорусский язык» („Generalní Staut“, 1997, с. 14).

Однако подобное положение не могло разрешить языковую проблему региона, поскольку, называя официальным языком русинский, правительство брало на себя 
масштабную задачу кодифицировать этот славянский язык и внедрить единую литературную норму в систему школьного образования.

Для организации учебного процесса на русинском языке были необходимы грамматики и учебники, отражающие эту новую языковую норму. Безусловно, первые попытки создать единую грамматику языка карпатских славян были предприняты еще до распада Австро-Венгерской империи. Начало процесса кодификации русинского языка было положено в конце XVIII века изданием книги Арсения Коцака (1737-1800) «Грамматика русская сиречь правила извещательная и наставительная о словосложении слова языка славенского или русского» (последняя редакция 1788 г.)

Коцак во многом опирался на грамматику церковнославянского языка Смотрицкого (создавалась в 1618-1619 гг.) и принимал русский язык за основу для кодификации русинского. В этой связи можно еще отметить также грамматику Михаила Михайловича Лучкая (1789-1843), изданную в Вене на латинском языке в 1830 г.: «Grammatica Slavo-Ruthena seu Vetero-Slavicae lingua».

Bсе ранние грамматики основывались на понимании русинского языка как диалекта великорусского. В этом направлении двигались и первые исследователи, предпринимавшие попытки осмысления русинской национальной идентичности. В первую очередь, это работы XIX века, которые были написаны русинами, обосновавшимися в Петербурге (Орлай, 1804).

Против русофильства, господствующего в среде русинской элиты, выступал Бенеш, пытаясь доказать безосновательность стремлений связать русинские наречия с великорусским языком. Бенеш относил начало русофильства в этом регионе с военной кампанией 1848-1849 г. (помощь русской армии в подавлении Венгерского восстания), подчеркнув тем самым краткость истории русофильства в этом регионе, что лишь отчасти соответствовало правде (действительно, оживления русофильских настроений было спровоцировано пребыванием в регионе русской армии):

«Эпизод 1848-1849 гг., когда русские войска вступили на венгерскую территорию, оставил глубокий след в сердцах угорских русинов и определил направление их национального возрождения: пришло время русофильского мессионерства, которое привело к принятию русского языка в качестве литературного и изменило процесс самостоятельного развития языка и нации» (Beneš, 1996, с. 8).

К началу XX века на территориях Подкарпатской Руси получила распространение еще одна теория, которая соотносила язык подкарпатских областей с украинским 
диалектом и, соответственно, предлагала кодифицировать его на основе украинского. Однако идеи о сущестовании отдельного русинского языка, определявшего не только национальность, но и страну - Русинско, до образования Подкарпатской Руси не было. Вероятно, мысль о возможном создании русинской автономии возникла под воздействием основных идеологических установок Парижской мирной конференции, которые закрепляли право нации на самоопределение и образование государства. Таким образом, для того, чтобы Подкарпатская Русь была признана как новое государственное образование (автономия в рамках Чехословакии), необходимым условием становилось наличие всех атрибутов государствообразующего народа, среди которых важное место занимали язык, культурная общность и культурная память.

Однако русинское сообщество, еще не готовое к широкой политической, культурной и административной автономии, оказалось не готовым и к кодификации русинского языка без опоры на русский или украинский. Желание чехословацких властей признать существование еще одного славянского племени и еще одного восточнославянского языка опережало реальность.

Русинский культурный деятель и школьный инспектор Игорь Гусьнай в брошюре «Языковой вопрос в Подкарпатской Руси», вышедшей в 1921 г., заявлял: «В Подкарпатской Руси замечается в последнее время полный хаос в языковым отношении» (Гусьнай, 1921, с. 1). Гусьнай однозначно решал вопрос о судьбе отдельного русинского языка (орфография авторская): «На деле расходится здесь только о две културные ориентации, русскую или украинскую, ибо третий узкотерриториальный «русинский» провинциализм никогда плодоносным быть не может» (Гусьнай, 1921, с. 3). О необходимости «odpolitizovat» («отполитизировать») языковые споры в Подкарпатской автономии, вывести их в сферу научной лингвистической дискуссии, писал и Яромир Нечас, который в статье «Politická situace na Podkarpatské Rusi» сделал следующий вывод: языковой вопрос нужно решать как научную проблему, необходимо срочно изменить сложившуюся в регионе ситуацию. Нечас утверждал, что более всего область страдает не из-за экономической отсталости, которая является привычной для данного региона, но из-за «политической филологии», ввергнувшей образованные элиты в хаос (Nečas, 1997, с. 60). О том, насколько велико было влияние языкового вопроса на стабильность региона, свидетельствуют строки из меморандума, направленного в канцелярию президента Республики членами русофильского общества им. Александра Духновича в Ужгороде: 
«...то, что творится сейчас в школьном образовании, вызывает у нас недоверие и разочарование. Вместо литературного русского языка повсеместно введен в наших школах вымышленный „русинский язык”. Наши учителя в большинстве своем - украинские сепаратисты, которые пришли из Галиции и стараются создать новый „русинский язык”» („Memorandum deputace“, 1997, с. 46).

Авторы этого меморандума оперируют понятием «украинские сепаратисты» авторы новых школьных учебников. Вероятно, речь идет о деятельности Августина Ивановича Волошина (1874-1945), директора учительской семинарии в Ужгороде. Этот русинский культурный деятель, действительно, был автором целого ряда учебников и школьных хрестоматий. Наиболее известна его работа 1901 г. «Методическая грамматика угро-русского литературного языка для народных школ» (Волошин, 1901, 1902, 1906). Это пособие были переиздано в 1919 г. под несколько измененным названием: «Методическая грамматика карпато-русского языка для народных школ». Представляется, что именно это издание вызвало негодование в пророссийски настроенной среде и стало причиной появления довольно радикальной брошюры Гусьная, отстаивающего необходимость повсеместного введения великорусского языка.

Волошин вступил в дискуссию с Гусьнаем и в 1921 г. издал основательное пояснение своей позиции по вопросам карпато-русского языка: «О письменном языце подкарпатских русинов» (Волошин, 1921). В этой работе Волошин открыто полемизировал с Гусьнаем и пытался найти альтернативное решение проблем, поставленных «русинскими московфилами». Высказавшись в печати о состоянии русинского языка, Волошин показал, что понимает, к кому была обращена полемичная работа Гусьная.

В 1921 г. Волошин придерживался умеренной позиции и считал, что ни русский, ни украинский не смогут заменить народного наречия русинов, а значит следует искать иной путь для разрешения конфликта. Он предлагал следующее решение: «урядовый язык повинен быть малоруській с этимологичным правописом» (Волошин, 1921, с. 9). При этом Волошин очень осторожно заметил, что в ряды русинской элиты проникла «якась непріятельска сила», которая вызвала все эти споры, разделила общество, и добавил, что до присоединения к Чехословакии подобного хаоса не было (Волошин, 1921, с. 10).

Представляется, что именно «политизация» языковых дискуссий, спровоцированная крайне размытой в 1919-1920 гг. подкарпатской политикой правительства 
Чехословакии, стала причиной разделения русинской интеллигенции на два лагеря «галицийских псевдо-украинских сепаратистов» и «москвофилов-фанатиков» (оба выражения принадлежат Волошину, который активно использовал их на страницах своей книги «О письменном языце подкарпатских русинов»). Однако жителей Подкарпатской Руси эти дискуссии касались мало, поскольку уровень грамотности в регионе неверное написание, нужно к 1930-му году, после десятилетия культурно-просветительской работы, едва достиг 40\%.

Мы обозначили в общих чертах основные проблемы, связанные с языковой и культурной ситуацией на территории Подкарпатской Руси в 1920-е гг. Изучение этих пограничных областей еще только начинается в российской славистике. Важно отметить несколько основных направлений для развития будущих исследований: лингвистическое, затрагивающее вопросы кодификации русинского языка; культурологическое и историко-литературное, предметом которого могут являться работы русских и украинских ученых, приехавших в Чехословакию в рамках «Русской акции» чехословацкого правительства и участвовавших в культурной и научной жизни региона.

\section{Библиография:}

Beneš, E. (1996). Podkarpatsko a jeho vztah k Československu. Praha: Česká Expedice.

Generalní Staut pro organisaci a administraci Přikarpatské Rusi. (1997). In J. Hořec (Ed.), Dokumenty o Podkarpatské Rusi (pp. 12-14). Praha: Česká Expedice.

Hartl, A. (1924). Kulturní život osvobozené Podkarpatské Rusi. Praha: Nákladem Grafického, Knihařského a nakladatelského družstva.

Hora, A. (1919). Podkarpatská Rus: přehled poměrů Karpatoruských. Praha: Vydavá Československý Cizinecký Úřad.

Kochanyj-Goralčuk, K. (1931). Podkarpatská Rus v minulosti a prítomnosti. Praha: Státní Nakladatelství.

Krofra, K. (1995). Podkarpatská Rus a Českoskovensko. Praha: Česká Expedice.

Memorandum deputace selského stavu. (1997). In J. Hořec (Ed.), Dokumenty o Podkarpatské Rusi (pp. 42-48). Praha: Česká Expedice.

Memorandum o Podkarpatské Rusi. (1997). In J. Hořec (Ed.), Dokumenty o Podkarpatské Rusi (pp. 5-11). Praha: Česká Expedice.

Nečas, J. (1997). Politická situace na Podkarpatské Rusi (rok 1921). Praha: Česká Expedice. Šafařík, P. (1826). Geschichte der slawischen Sprache und Literatur nach allen Mundarten. Ofen. 
Волошин, А.И. (1901). Методическая грамматика угро-русского литературного языка для народных школ. Унгвар: Вид-во тов-ва «Просвіта».

Волошин, А. И. (1902). Материнскій язык в народной школе: короткія руководяшія заметки для народных учителей. Унгвар: Вид-во тов-ва «Просвіта».

Волошин, А. И. (1906). Азбука угро-русскаго и церковно-славянскаго чтенія. Унгвар: Вид-во тов-ва «Просвіта».

Волошин, А. И. (1921). О письменном языце подкарпатских русинов. Ужгород: Вид-во тов-ва «Просвіта»; Лит. наук. отдел.

Гусьнай, И. (1921). Языковой вопрос в Подкарпатской Руси. Пряшев: Книгопечатня „Св. Николая».

Духнович, А. В. (1981). Истинная история Карпато-Россов. Монтреал.

Лучкай, М. М. (1999-2004). Історія карпатських русинів. Ужгород: Ужгородський держ. ун-т.

Орлай, И. С. (1804). История о карпато-россах или о переселении россиян в Карпатские горы и о приключениях с ними случившихся. Северный Вестник, (6-9).

\section{Bibliography:}

Beneš, E. (1996). Podkarpatsko a jeho vztah k Československu. Praha: Česká Expedice.

Dukhnovich, A. V. (1981). Istinnaia istoriia Karpato-Rossov. Montreal.

Generalní Staut pro organisaci a administraci Přikarpatské Rusi. (1997). In J. Hořec (Ed.), Dokumenty o Podkarpatské Rusi (pp. 12-14). Praha: Česká Expedice.

Gus'nă̆, I.(1921). lazykovoĭ vopros v Podkarpatskoǐ Rusi. Priashev: Knigopechatnia „Sv. Nikolaia». Hartl, A. (1924). Kulturní život osvobozené Podkarpatské Rusi. Praha: Nákladem Grafického, Knihařského a nakladatelského družstva.

Hora, A. (1919). Podkarpatská Rus: přehled poměrů Karpatoruských. Praha: Vydavá Československý Cizinecký Úřad.

Kochanyj-Goralčuk, K. (1931). Podkarpatská Rus v minulosti a prítomnosti. Praha: Státní Nakladatelství.

Krofra, K. (1995). Podkarpatská Rus a Českoskovensko. Praha: Česká Expedice.

Luchkă̆, M. M. (1999-2004). Istoriiia karpats'kikh rusinīv. Uzhgorod: Uzhgorods'kiĭ derzh. un-t. Memorandum deputace selského stavu. (1997). In J. Hořec (Ed.), Dokumenty o Podkarpatské Rusi (pp. 42-48). Praha: Česká Expedice.

Memorandum o Podkarpatské Rusi. (1997). In J. Hořec (Ed.), Dokumenty o Podkarpatské Rusi (pp. 5-11). Praha: Česká Expedice.

Nečas, J. (1997). Politická situace na Podkarpatské Rusi (rok 1921). Praha: Česká Expedice. 
Orlaĭ, I. S. (1804). Istoriia o karpato-rossakh ili o pereselenii rossiian v Karptskie gory i o prikliucheniiakh s nimi sluchivshikhsia. Severnyĭ Vestnik, (6-9).

Šafařík, P. (1826). Geschichte der slawischen Sprache und Literatur nach allen Mundarten. Ofen.

Voloshin, A. I. (1901). Metodicheskaia grammatika ugro-russkogo literaturnogo iazyka dlia narodnykh shkol. Ungvar: Vid-vo tov-va «Prosvīta».

Voloshin, A. I. (1902). Materinskĭ iazyk v narodnoĭ shkole: korotkïia rukovodiashchïia zametki dlia narodnykh uchitelel̆. Ungvar: Vid-vo tov-va «Prosvīta».

Voloshin, A. I. (1906). Azbuka ugro-russkago i tserkovno-slavianskago chtenïia. Ungvar: Vid-vo tov-va «Prosvīta».

Voloshin, A. I. (1921). O pis'mennom iazytse podkarpatskikh rusinov. Uzhgorod: Vid-vo tov-va «Prosvīta»; Lit. nauk. otdel.

\section{Subcarpathian Rus as a part of Czechoslovakia: history, culture, national identity}

Subcarpathian Rus was incorporated into the First Czechoslovak Republic as a result of the Treaty of Saint-Germain-en-Laye (1919). The following year Subcarpathian Rus being a part of Czechoslovakia was declared a self-governing autonomy with a certain number of democratic rights established by the Constitution. Among them was a right to use their national language. Codification of the Subcarpathian Ruthenian language has not yet been completed and it is an extensively discussed problem for contemporary linguists.

After the First World War the Subcarpathian lands with its Ruthenian population was a poor farming region with a low level of ethnic self-awareness. Global economic and politic processes changed the situation dramatically and compelled the educated part of Subcarpathian Rus citizens into a discussion about their national language, culture and literature. The President of Czechoslovakia T. G. Masaryk participated in the discussion and was very interested in the cultural development of the region.

Ruthenian society was split into two parts - pro-Russian and pro-Ukrainian. The national composition of the region was very complicated. In order to understand the flow of national ideas in Subcarpathian Rus, the research presented here sets out to cover the history of the codification of the Ruthenian language, the creation of grammar books for schools, and to analyze the role of both the Russian and Ukrainian components in the cultural development of this region. This research also takes into consideration the complex analysis of Masaryk's Slavonic policy and cultural strategies.

\section{Keywords:}

Boarder studies; Czechoslovakia; Subcarpathian Rus; Ruthenia; minor Slavic languages; national identity 